\title{
THE NUMBER OF DIGITAL PAD SCALES - A NEW SEX CHARACTER IN THE CHICK?
}

\author{
A. HAMPL \\ Department of Anatomy and Physiology of Farm Animals University of Agriculture, 61300 Brno
}

Received February 7, 1992

\begin{abstract}
Hampl A.: The Number of Digital Pad Scales - a New Sex Character in the Chick? Acta vet. Brno, 61, 1992: 93-98.

The conformation of the skin relief of soleal surface of the pulvinus digitalis distalis of the third digit (PDD III) was studied in two groups of one-day-old chicks. Besides, the length and width of PDD III and the width of the digital claw base were estimated in one group of chicks. These studies gave the following results: The soleal surface of PDD III has a corrugated relief resulting from the presence of small scales which do not overlap each other. The shape of scales depends on the localisation of scales on the pad; near its circumference elongated scales predominate while in its central part those of rounded and polygonal shape may be mostly found. Scales are arranged in 4 main and $2-3$ accessory rows. The main rows are arched from the medial towards the lateral edge of the pad while the accessory ones are incomplete and situated between the main rows. The total numbers of scales on PDD III are the same on both legs and they are significantly higher in males than in females. The size of PDD III and the width of claw base show bilateral symmetry and are identical in both sexes.
\end{abstract}

Digital pad, skin relief, avian scale, sexing, chick

A rapid and exact sexing of one-day-old chicks is one of categoric requirements of poultry husbandry. Regardless to all well-known anatomical features of sexual dimorphism I tried to find and to define another character which would enable the use of an automatic image analysis system for sexing the chicks. It seemed that the number of scales on the PDD III could be such a suitable feature.

The morphological description of the relief configuration of non-feathered skin of avian foot is quite insufficient in many textbooks and handbooks of avian anatomy ( $\mathrm{Schwarze}$ and Schröder 1972; Koch 1973; Schummer 1977; Komárek et al. 1982) and it can be used only as basic information. A more detailed characterization of scales covering the tarsometatarsus and digits of birds (as far as comparative and topographic anatomy, morphogenesis and microscopic structure are concerned) can be found in studies published by several authors (e. g. Boetticher 1930; Blaszyk 1935; Lucas and Stettenheim 1972; Sawyer 1972; Sengel 1976 and Puchkov 1979). However, these authors did not mention any other feature of sexual dimorphism in the configuration of podotheca excepting the metatarsal spur.

\section{Materials and Methods}

Two groups of one-day-old chicks were used in this study. Their sex was exactly determined by inspection of gonads after laparotomy. The first group (G 1) involved 28 males and 34 females of the parent breeding stock of Rhode Island White maternal line and Rhode Island Red paternal line, respectively. The second group (G 2) involved progeny obtained on the base of back-crossing of cocks (White Leghorn) and their daughters (White Leghorn $\times$ Black Minor); this group involved 35 males and 35 females.

Both feet of each individual, cut in the intertarsal ioint, were preserved in 5-per-cent formol solution. The configuration of the relief of soleal surface of PDD III was studied under a dissecting microscope of 12.5 times magnifying power. In chicks of $\mathrm{G} 1$ only the total number of digital 
pad scales and their distribution into main and accessory rows were investigated while in those of G 2 also the length and width of PDD III and the width of the base of digital claw were evaluated using an ocular micrometer with the accuracy of $74 \mu \mathrm{m}$. The obtained data were analyzed statistically and the significance of differences was estimated by means of Student's t-test.

\section{Results}

The PDD III situated in the plantar region of distal interphalangeal joint is of ovoid shape; its wider convex end is oriented distally. The narrower pole of the pad is oriented in the proximal direction and is separated from the lower interpad space by a markedly transversal groove. This groove may be either straight or slightly bent in the distal direction. The soleal surface of digital pad is strongly convex both transversally and longitudinally and there are numerous small tubercular scales dispersed on it. However, the shape of individual scales is not quite uniform and there are considerable differences in it depending on their position on the digital pad. It can be observed that scales of elliptic, drop-like or rhomboid shape predominate in the medial and lateral margin of the pad; in the central part of digital pad, above all scales are rounded or slightly polygonal in shape. Scales situated at the proximal edge of the pad are mostly semispherical, drop-like or triangular and, towards the transversal groove, they fuse to a different extent. The relatively largest scales may be found in the distal circumference of the pad; they are in contact with the soleal surface of digital claw. Their shape resembles elongated plates with widened and rounded proximal edges. All scales of PDD III have smooth edges and are separated by shallow or deeper grooves; they never overlap each other.

Although it could seem at first sight that the scales are situated irregularly on the surface of the pad, it is obvious when studying them in greater detail that they are arranged in four main rows and two to three accessory rows (Fig. 1). As the main rows those series of scales are denoted which, being situated side by

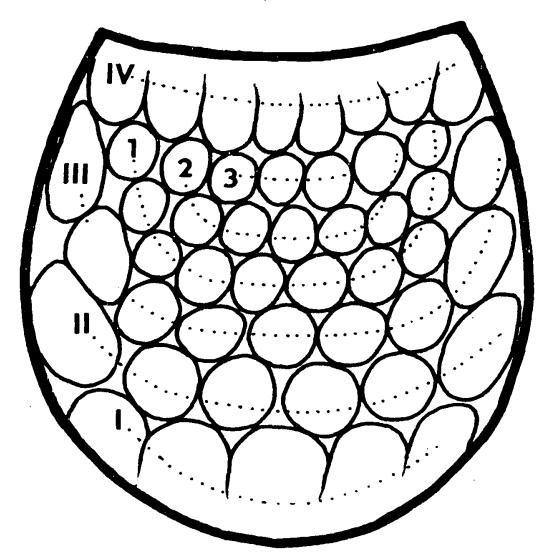

A

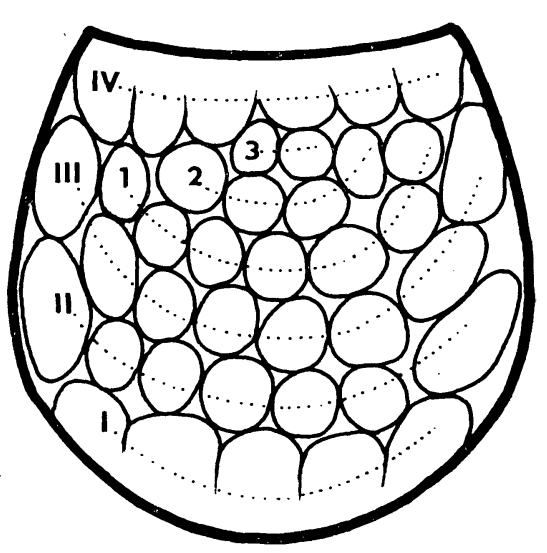

B 
Number of scales, size of PDD III and width of claw base of the left (sin.) and right (dx.) foot in chicks G1 and G2

\begin{tabular}{|c|c|c|c|c|c|}
\hline \multirow[t]{2}{*}{ Trait } & & \multicolumn{2}{|c|}{ Males } & \multicolumn{2}{|c|}{ Females } \\
\hline & & $\sin$ & $\mathrm{dx}$. & $\sin$ & $\mathrm{dx}$. \\
\hline Number & $\mathbf{n}$ & 28 & 28 & * 34 & $34^{\prime}$ \\
\hline $\begin{array}{c}\text { of scales } \\
\text { G1 }\end{array}$ & $\begin{array}{l}\text { MEAN } \\
\text { SD } \\
\text { SE } \\
\text { CV (\%) }\end{array}$ & $\begin{array}{c}41,6 a \\
6,1 \\
1,2 \\
14,6\end{array}$ & $\begin{array}{c}40,8 \mathrm{a} \\
5,2 \\
1,0 \\
12,7\end{array}$ & $\begin{array}{c}35,9 \mathrm{~b} \\
4,8 \\
0,8 \\
13,3\end{array}$ & $\begin{array}{c}35,1 \mathrm{~b} \\
4,6 \\
0,8 \\
13,1\end{array}$ \\
\hline Number & $\mathbf{n}$ & 35 & 35 & 35 & 35 \\
\hline $\begin{array}{c}\text { of scales } \\
\text { G2 }\end{array}$ & $\begin{array}{l}\text { MEAN } \\
\text { SD } \\
\text { SE } \\
\text { CV }(\%)\end{array}$ & $\begin{array}{c}46.5 \mathrm{a} \\
4.7 \\
0.8 \\
10.2\end{array}$ & $\begin{array}{c}46.1 \mathrm{a} \\
5.1 \\
0.9 \\
10.9\end{array}$ & $\begin{array}{l}40.7 \mathrm{~b} \\
2.4 \\
0.4 \\
5.8\end{array}$ & $\begin{array}{c}40.4 \mathrm{~b} . \\
2.9 \\
0.5 \\
7.2\end{array}$ \\
\hline Length & $\mathrm{n}$ & 35 & 35 & 35 & 35 \\
\hline $\begin{array}{l}\text { of PDD III } \\
(\mu \mathrm{m}){ }_{\text {G2 }}\end{array}$ & $\begin{array}{l}\text { MEAN } \\
\text { SD } \\
\text { SE } \\
\text { CV (\%) }\end{array}$ & $\begin{array}{r}2779.3 \\
120.6 \\
20.4 \\
4.3\end{array}$ & $\begin{array}{r}2839.3 \\
128.8 \\
21.8 \\
4.5\end{array}$ & $\begin{array}{r}2721.4 \\
136.8 \\
23.1 \\
5.0\end{array}$ & $\begin{array}{r}2760.0 \\
120.4 \\
20.3 \\
4.4\end{array}$ \\
\hline Width & $\mathrm{n}$ & 35 & 35 & 35 & 35 \\
\hline $\begin{array}{c}\text { pf PDD III } \\
\underset{(\mu \mathrm{m})}{\mathrm{G} 2}\end{array}$ & $\begin{array}{l}\text { MEAN } \\
\text { SD } \\
\text { SE } \\
\text { CV }(\%)\end{array}$ & $\begin{array}{r}2498.6 \\
82.9 \\
14.0 \\
3.3\end{array}$ & $\begin{array}{r}2455.7 \\
108.1 \\
18.3 \\
4.4\end{array}$ & $\begin{array}{r}2477.1 \\
76.1 \\
12.9 \\
3.1\end{array}$ & $\begin{array}{r}2421.4 \\
111.5 \\
18.8 \\
4.6\end{array}$ \\
\hline Width & $\mathrm{n}$ & 35 & 35 & 35 & 35 \\
\hline $\begin{array}{c}\text { of claw base } \\
(\mu \mathrm{m}) \\
\mathrm{G} 2\end{array}$ & $\begin{array}{l}\text { MEAN } \\
\text { SD } \\
\text { SE } \\
\text { CV }(\%)\end{array}$ & $\begin{array}{r}1416.4 \\
62.4 \\
10.5 \\
4.4\end{array}$ & $\begin{array}{r}1382.1 \\
52.4 \\
8.9 \\
4.8\end{array}$ & $\begin{array}{r}1405.7 \\
68.9 \\
11.6 \\
4.9\end{array}$ & $\begin{array}{r}1377.9 \\
81.5 \\
13.8 \\
5.9\end{array}$ \\
\hline
\end{tabular}

Means bearing different suffixes showed significant differences $(P<0.001)$.

side, run from the medial towards the lateral edge of pad. The most distal first: row (I) follows the convexity of the edge of PDD III along the hyponychium of digital claw. The second and the third row (II and III) are situated more pro-ximally and run in arches parallel with row I. The fourth row (IV) follows the interpulvinary groove and represents the proximal edge of pad. Accessory rows $(1,2,3)$ are composed of scales which do not reach as far as to the lateral and medial edge of pad; they are enclosed within the space demarcated by the main. rows III and IV.

Due to the fact that individual scales of neighbouring rows show a zip-like pattern it is possible to observe a characteristic hexagonal arrangement of scales. Regarding the differences in the size of scales it is sometimes possible to observe also a pentagonal and or heptagonal distribution pattern of scales.

Numbers of scales in individual rows are not identic and show certain differences. This range is practically the same on both legs and is a little wider in males than in females.

Total numbers of scales counted on PDD III are summarized in Tab. 1. As one can see, G 1 males had higher numbers of scales on both legs than females (in average by $16 \%$ ). However, there were great individual differences in numbers of scales; in males this range was 28 to 51 and 30 to 49 on the left and the right leg, respectively, while in females the numbers of scales ranged from 25 to 44 on both legs. As compared with G 1 chicks, those of G 2 had markedly: 
higher numbers of scales on digital pads: in males this increase was by $12 \%$ and $13 \%$ on the left and the right side, resp., while in females the corresponding numbers were $13 \%$ and $15 \%$, resp. In spite of these increased numbers the sexual differences in scale numbers were markedly expressed also in G 2: the number of scales was higher in males by $14 \%$ on both legs. Also in this group of chicks there were great individual differences in numbers of scales (in males these values ranged from 39 to 60 and from 36 to 59 on the left and the right side, resp. while in females this range was 36 to 45 and 34 to 46 on the left and the right leg, resp.).

The size of PDD III (as expressed by means of the maximum length and width) was very uniform, without any significant differences between the right and the left leg as well as between both sexes; the ratio length/width was identic ( $1: 0.9)$.

Similarly to the size of PDD III, also the width of claw base (measured from the plantar size immediately at the distal edge of PDD III) was highly uniform and without any significant differences between the left and the right leg and/or between both sexes.

\section{Discussion}

The obtained data represent original morphological findings which indicate that the size of PDD III and the width of claw base are features showing no relationship to the sex of chicks. On the other hand, however, the total number of scales on distal digital pad represents, in my opinion, a morphological feature closely related to sex; this was demonstrated also by statistically highly significant intersexual differences. This interpretation was corroborated also by the fact that the same relationship was demonstrated in two groups of chicks of quite different genotypes.

Unfortunately, an immediate practical application of this sexual trait is at present prevented by a relatively high variability of the number of scales which is associated with a certain overlapping of male and female variants. The solution of this problem may lie in selection and other genetic methods enabling to obtain such a line in which this trait could be used for a reliable sexing. In this context it is also very suitable that there is a significant bilateral symmetry in numbers of scales; this enables to use any leg for the prospective sexing.

Regarding the great number of pad scales and their small size it is necessary to say that it is quite impossible to think that the trait could be used for routine, rapid, exact and prolonged sexing of chicks by naked eye or by means of a magnifying device. This can be done only by means of machine sexing based on an automatic image analysis of skin relief of PDD III.

\section{Počet šupin prstního polštáře - nový sexuální znak u kuřete?}

S cílem postihnout a bliže charakterizovat exteriérové znaky, které by mohly být využity $\mathrm{k}$ sexaci kuřat na principu automatické analýzy obrazu, bylo $u$ dvou skupin jednodenních kuřat vyšetřeno morfologické utváření kožního reliéfu chodidlové plochy distálního prstního polštáře třetího prstu (PDD III). U jedné skupiny kuřat byla navíc zjištěna délka a šírka PDD III a šírka báze drápu. Stu.dium přineslo následující výsledky: 
Chodidlová plocha PDD III má členitě utvářený reliéf $\mathrm{v}$ podobě drobných šupin, které se navzájem nepřekrývají. Šupiny mají různý tvar podle svého umístěni na polštáři; při obvodu polštáře převažuji šupiny protáhlého tvaru, $v$ jeho středové části okrouhlého a polygonálního tvaru. Šupiny jsou uspořádány do 4 hlavních a $2-3$ vedlejších řad. Hlavní řady probíhaji v obloucích od mediálního $\mathrm{k}$ laterálnímu okraji polštáře, vedlejší řady jsou neúplné a jsou umístěny mezi hlavními řadami. Celkový počet šupin PDD III je na obou končetinách shodný a je statisticky signifikantně vyšší u kohoutků než u slepiček. Rozměny PDD III i šírka báze drápu vykazují bilaterální symetrii a jsou u obou pohlaví shodné.

\section{Численность чешуек подүшечки пальца - новый половой признак цыплят?}

Для определения и более точной характеристики внешних признаков, которые можно было бы использовать для установления половой характеристики цыплят на принципе автоматического анализа внешнего облика, на двух группах суточного возраста цыплят проводили исследования морфологического образования поверхности дистальной подушечки третьего пальца (PDD III). Более того, у одной группы цыплят устанавливали длину и ширину PDD III и ширину основания когтя. Исследования вылились в следующие результаты:

Поверхность PDD III отличается расчлененным рельефом в форме мелких чешуек, взаимно не перекривающихся. У чешуек разная форма, смотря по расположению на подүшечке. В окружности подушечки преобладающими являются чешуйки продолговатой формы, в центральной части - кругообразной и полигональной форм. Чешүйки расположены в 4 основных и 2-3 второстепенных рядах. Основные ряды проходят дүгой, начиная с медиального до латерального краев подүшечки, второстепенные - неполные и расположены между основными рядами. Общая -численность PDD III чешуек на обеих конечносткх тождестценна и статистически явно больше у петушков по срагнению с курицами. Размеры PDD III и ширина когтя в его основании отличаются билатеральной симетрией и совпадением у обеих полов.

\section{Acknowledgement}

The author is deeply indepted to Ass. Prof. Ing. S. Jeřábek, CSc., Poultry Station of the University of Agriculture Brno for his kind provision of chicks G 1 and to Ing. J. Plachý, CSc., Institute of Molecular Genetics of the Czechoslovak Academy of Sciences Prague for chicks G 2.

\section{References}

BLASZYK, P.: Untersuchungen über die Stammesgeschichte der Vogelschuppen und Federn und über die Abhängigkeit ihrer Ausbildung am Vogelfuss von der Funktion. Gegenbaurs mornhologisches Jahrbuch, 75, 1935: 483-567

BOETTICHER, H.: Morphologische und phylogenetische Studien über die hornige Fussbekleidung der Vögel. Ienaische Zeitschrift für Naturwissenschaft, 64, 1930: 377-448

$\mathrm{KOCH}, \mathrm{T} .:$ Anatomy of the chicken and domestic birds. The Iowa State University Press, Ames, Iowa, 1973, pp. $145-150$ 
KOMÁREK, V. - MALINOVSKÝ, L. - LEMEŽ, L.: Anatomia avium domesticarum et embryologia galli II, III. Príroda, Bratislava, 1982, pp. 140-141

LUCAS, A. M.-STETTENHEIM, P. R.: Avian anatomy. Integument I, II. Washington, D. C., 1972 , pp. $64-72,595-612$

SAWYER, H. G.: Avian scale development I, II. Journal of Experimental Zoology, 181, 1972: $365-408$

SCHUMMER, A.: Anatomy of the domestic birds. Verlag Paul Parey, Berlin, Hamburg, 1977, pp. $157-158$

SCHWARZE, E. - SCHRÖDER, L.: Kompendium der Geflügelanatomie. VEB Gustav Fischer Verlag Jena, 1972, pp. 233-242

SENGEL, P.: Morphogenesis of skin. Cambridge University Press, London, New York, Melbourne, Cambridge, 1976, pp. 48-53, 239-246

PUCHKOV, V. F.: Razvitiye shpor u zarodyschey cyplenka. Archiv anatomiyi, gistologiyi i embryologiyi, 76, 1970: 32-41 